\title{
Wyrok Sądu Metropolitalnego w Katowicach (c. Sobański) z 21.12.2004 z tytułu niezdolności pozwanej do podjęcia i wypełnienia istotnych obowiązków małżeńskich
}

Ius Matrimoniale 10 (16), 217-220

2005

Artykuł został opracowany do udostępnienia w internecie przez Muzeum Historii Polski w ramach prac podejmowanych na rzecz zapewnienia otwartego, powszechnego i trwałego dostępu do polskiego dorobku naukowego i kulturalnego. Artykuł jest umieszczony w kolekcji cyfrowej bazhum.muzhp.pl, gromadzącej zawartość polskich czasopism humanistycznych i społecznych.

Tekst jest udostępniony do wykorzystania w ramach dozwolonego użytku. 


\section{Wyrok Sąu Metropolitalnego w Katowicach (c. Sobański) z 21.12.2004 z tytułu niezdolności pozwanej do podjęcia i wypełnienia istotnych obowiązków małżeńskich}

\section{Przebieg sprawy:}

TŁ oraz BJ zawarli małżeństwo 5.1.1991 w kościele św. Maksymiliana w (...). Ważność tego małżeństwa zaskarżył TŁ 22.5.2001 w Sądzie Metropolitalnym w (...). Sprawę rozpatrywano z tytułu wykluczenia wierności przez pozwaną oraz niezdolności do podjęcia istotnych obowiązków małżeńskich przez pozwaną oraz/lub powoda. Wyrokiem z 31.1.2002 orzeczono, iż nie udowodniono nieważności małżeństwa z żadnego z rozpatrywanych tytułów. Wskutek apelacji powoda sprawa znalazla się w Trybunale II instancji, tj. w Sądzie Metropolitalnym w (...). Sąd ten, po wzbogaceniu materiału dowodowego, orzekl 28.4.2004, że nie udowodniono nieważności małżeństwa z tytułu wykluczenia wierności przez pozwaną ani z tytułu niezdolności powoda do podjęcia istotnych obowiązków małżenskich, udowodniono natomiast takąż niezdolność po stronie pozwanej. Na popartą przez Oficjala Sądu Metropolitalnego (...) prośbę powoda Najwyższy Trybunał Sygnatury Apostolskiej reskryptem z 12.6.2004 wyznaczyl Sąd Metropolitalny w Katowicach do rozpatrzenia sprawy w III instancji. Akta sprawy poprzednich instancji nadeszły 30.7. i 2.9.2004. Strony nie przedłożyły nowych wniosków dowodowych. Przedmiotem sprawy w III instancji jest pytanie, czy udowodniono nieważność małżeństwa z tytułu niezdolności pozwanej do podjęcia istotnych obowiązków małżeńskich. Pytanie to jest równoznaczne z pytaniem, czy należy zatwierdzić wyrok Trybunału II instancji w części orzekającej nieważność małżeństwa. Podejmując powyższe pytanie Sąd udziela odpowiedzi jak następuje:

\section{Prawny i faktyczny stan sprawy:}

1. Normy prawa mające zastosowanie w rozpatrywanej sprawie wyłożono w wyrokach poprzednich instancji i nie zachodzi potrzeba powtarzania ich. 
2. Pozwana zeznaje o sobie, że nie sprawiała rodzicom trudności wychowawczych, podczas studiów dorabiała, aby odciążyć finansowo rodziców, tańczyła też w zespole ludowym. Podaje, że to ona wyszla z planami matrymonialnymi, bo chciała dodać powodowi odwagi i utwierdzić go w przekonaniu, że jest pełnowartościowym czlowiekiem. Twierdzi, że obydwie strony decydowały się z miłości na małżeństwo i uczestniczyły w przygotowaniach, dzień zaślubin był bardzo podniosły, jednak po ślubie czuła się bardzo osamotniona, bo powód był w ciągłych rozjazdach, a przygotowane przez nią obiady lądowały w koszu na śmieci. Powód „nie potrafił rozmawiać w małżeństwie”, stawiał ją wciąż przed faktem dokonanym. Pozwana trzykrotnie zachodziła w ciążę i za każdym razem dochodziło do poronienia. Powód zarzucal jej, że jest nic nie warta. W cztery lata po ślubie nawiązała bliższą znajomość z innym mężczyzną, zerwała po roku, ale małżeństwa nie udalo się już utrzymać.

Przesłuchana ponownie w II instancji nie wniosła do sprawy nic, co miałoby znaczenie w świetle rozpatrywanego tytułu.

3. W zeznaniach powoda brak nawet poszlak mogących uzasadnić tezę o niezdolności pozwanej do podjęcia istotnych obowiązków malżeńskich. Według powoda problemy w małżeństwie pojawily się po pięciu latach małżeństwa, gdy otrzymał informacje, że żona go zdradza.

4. W zeznaniach świadków znajdują się jedynie sporadyczne wypowiedzi o „bogatym życiu towarzyskim pozwanej”, brak natomiast informacji ważkich w świetle rozpatrywanego tytułu.

5. Biegła-psycholog powolana w I instancji przeprowadziła badanie testowe pozwanej, które - jak pisze - „daje podstawę do wnioskowania o zdolności pozwanej do samokontroli swojego zachowania". Główne cechy charakteru pozwanej to wedle biegłej, „wrażliwość, spontaniczność, łatwość w nawiązywaniu kontaktów, lecz słaba umiejętność regulowania wewnętrznych impulsów". Badanie testowe nie ujawniło zaburzeń osobowości pozwanej, analiza materiału dowodowego te $\dot{z}$ - według biegłej - nie daje podstaw do wnioskowania o takich zaburzeniach, stąd wniosek biegłej o zdolności pozwanej (podobnie jak powoda) „do nawiązywania prawidłowych relacji osobowych w małżeństwie".

6. Biegła powołana w II instancji poddała krytyce opinię biegłej I instancji. Zarzuca, że nie wskazano instrumentów (nazwy testu), jakimi biegła się posłużyła. Biegła II instancji przeprowadziła badanie czterema testami i doszła do wniosku, że u pozwanej „można stwierdzić po- 
ważne zaburzenia osobowości, szczególnie w sferze emocjonalno popędowej, które determinowały i komplikowały jej relacje osobiste, uniemożliwiając stały związek uczuciowy z jednym partnerem". Z tych względów uważa biegła, że „pozwana w chwili zawierania małżeństwa $\mathrm{z}$ powodem, nie była zdolna do podjęcia i wypełnienia istotnych obowiązków małżeńskich z przyczyn natury psychicznej”. Biegła przyznaje, iż „zaskakujące jest to, że w bezpośrednim kontakcie z pozwaną poza brakiem „osłony” psychicznej - nic nie wskazywało na występowanie jakichś zaburzeń, które zostały ujawnione przez patologiczne wyniki badań testowych". Właśnie tym tłumaczy Trybunał apelacyjny brak w zeznaniach świadków faktów i spostrzeżeń odnoszących się do defektów osobowościowych pozwanej.

7. Sąd respektuje wyniki wyprowadzone przez biegłą z badań testowych, ale nie mogą one być jedyną podstawą orzeczenia nieważności. Dowód z opinii biegłego można uznać za pełny dopiero wtedy, gdy opiera się on na analizie materiału dowodowego oraz na badaniu przeprowadzonym przez biegłego, na które z kolei winny składać się wywiad z osobą badaną oraz badanie testowe, wraz z omówieniem ich wyników. W opinii biegłej jedynymi przesłankami jej wniosku są wyniki testów. Nasuwa się przeto pytanie, czy w materiale dowodowym znajdują się fakty procesowo udowodnione harmonizujące z konkluzją biegłej wypowiadającej się w II instancji.

Otóż fakty te rysują się w zeznaniach samej pozwanej. Przyznaje ona, że nie potrafi „radzić sobie w długotrwałym związku”, „szybko angażuje się uczuciowo bez reszty", ale też szybko się „wypala”. Już przed nawiązaniem bliższej znajomości z powodem byla dwukrotnie głęboko zaangażowana, kolejny po rozstaniu z mężem związek również uważa za nieudany, nieustannie boi się - jak przyznaje - porzucenia. Te kolejne, wszystkie przeżywane z głębokim zaangażowaniem emocjonalnym i wysokimi oczekiwaniami wobec każdorazowego partnera (a także wobec siebie w każdym z nich) związki świadczą o defektach w sferze emocjonalno-popędowej powodujących, że pozwana nie potrafi tworzyć stabilnego związku z mężczyzną.

Nie można uznać pozwanej za niezdolną do nawiązania relacji międzyosobowej i wywiązywania się ze składających się na nią obowiązków. Trzeba natomiast uznać ją za niezdolną do relacji trwałej, nieodwołalnej, jaką ze swej istoty jest małżeństwo. Defekty emocjonalne nie pozwalają pozwanej trwać w oddaniu się drugiej osobie. Do tego stwierdzenia Sąd dochodzi drogą wnioskowania redukcyjnego, w kon- 
kluzji zbieżnego z wylożonymi przez biegłą Trybunału II instancji wynikami badania testowego. W ten sposób Sąd osiągnąl moralną pewność, że nawiązanie trwałej, nierozerwalnej wspólnoty małżeńskiej przerastało możliwości duchowe pozwanej. Nie ulega dla Sądu wątpliwości, że pozwana miała wystarczające rozeznanie co do małżeństwa oraz szczery zamiar jego zawarcia, co więcej angażowała się w małżeństwo i w związane z nim obowiązki. Zaangażowanie to kolejno okazywało się nietrwałe, a labilność ta charakteryzuje ją od lat szkolnych. Brak stałości i wytrwałości stanowi dla pozwanej niepokonalną przeszkodę w podołaniu nierozerwalności charakteryzującej małżeństwo w jego chrześcijańskim rozumieniu.

Wobec takiego stanu sprawy Sąd odpowiada twierdząco na pytanie procesowe i stwierdza że udowodniono nieważność małżeństwa $\mathrm{z}$ tytułu niezdolności pozwanej do podjęcia istotnych obowiązków małżeńskich. Tym samym Sąd zatwierdza wyrok Trybunału II instancji.

Pozwana nie może zawrzeć nowego małżeństwa bez uprzedniej zgody - de consilio periti - Ordynariusza miejsca.

Katowice, dnia 21 grudnia $2004 \mathrm{r}$. 